\title{
Bybelse modelle van die huwelik: 'n Kritiese perspektief
}

\author{
Anet E Dreyer \& Andries G van Aarde ${ }^{1}$ \\ Departement Nuwe-Testamentiese Wetenskap \\ Universiteit van Pretoria
}

\begin{abstract}
Biblical models of marriage: A critical perspective The Christian marriage finds itself in a crisis. Churches worldwide are struggling to find answers to address the problem in their communities. The book of Adrian Thatcher "Marriage after modernity, Christian marriage in postmodern times", is a resent publication which endeavours to formulate guidelines for marriage in postmodern society. This article is an attempt to give an overview of, as well as a critical reflection on the Biblical models as identified in his research. Although Thatcher's "models" are of utmost importance in the recent debate, it is necessary to select certain perspectives within his models that are still applicable in postmodern times. This first article describes and evaluates his models, whilst the second article focuses on the relevancy thereof in postmodern times.
\end{abstract}

\section{INLEIDING}

\subsection{Probleemstelling}

Binne 'n postmoderne era dring die besef al meer en meer deur dat die huwelik, soos wat ons dit tradisioneel verstaan het, onder geweldige druk verkeer. Die kerk word wêreldwyd gekonfronteer met die werklikheid van hoë egskeidingsyfers, huwelikskonflik, saamwoon, vrye seks en in die jongste tyd, die wettiging van homoseksuele huwelike en ander burgerlike verbintenisse. Kerke probeer om met die tradisionele teologiese verstaan van die huwelik die probleem op te los, maar slaag nie daarin om die konvensionele huweliks-

\footnotetext{
${ }^{1}$ Hierdie artikel is die verwerking van die eerste deel van A E Dreyer se MTh-skripsie, onder leiding van prof dr A G van Aarde, Departement Nuwe-Testamentiese Wetenskap, Fakulteit Teologie, Universiteit van Pretoria. Die skripsie het gedien as 'n oorsigartikel van die boek van A Thatcher (1999), Marriage after modernity: Christian marriage in postmodern times. England: Sheffield Academic Press.
} 
vorm af te dwing nie. Black (2004:97) noem skokkende syfers van onlangse statistieke: Die egskeidingsyfer in die VSA is tussen $29 \%$ en $50 \%$ vir eerste huwelike, terwyl 61 persent tot 76 persent van alle tweede huwelike op die rotse loop. Adrian Thatcher (1999:9) sê in sy boek, Marriage after modernity, Christian marriage in post modern times, ${ }^{2}$ dat die inkongruensie tussen die menslike ervaring van die huwelik en die "teologie van die huwelik" deur die eeue heen problematies was. Rosemary Haughton (1987:149) noem dit: "a theology of marriage shattered by experience."

Een van die mees resente boeke wat die problematiek rondom die hedendaagse huwelik indringend ondersoek, is die boek van Thatcher (1999). Vanuit 'n Bybels-hermeneutiese benadering poog Thatcher om in sy ontleding van die onderskeie Bybelse modelle, die invloed van die konteks in ag te neem en in die vertolking van die dinamiese inhoude vir vandag, gee hy ook deeglik rekenskap van die hedendaagse situasie en eise wat dit aan die huwelik stel. Daarom word sy boek gebruik as basis en raamwerk vir hierdie ondersoek. Ek wil egter die modelle wat Thatcher bespreek nie in isolasie beskou nie en ook nie een model verhef tot die ideaal nie, maar eerder kyk of 'n mens ' $n$ kombinasie van hierdie modelle kan gebruik om nuwe betekenis te gee aan die huwelik.

Hy bespreek in sy eerste hoofstuk waarom hy sy boek Marriage after modernity noem. In die eerste plek veronderstel "after modernity" dat die tyd van moderniteit verby is, dat ons die basiese konsepte van moderniteit kan identifiseer en dat ons kan uitsien na iets nuuts. Moderniteit word meestal geassosieer met: "... the triumph of science over other modes of knowledge, and a naïve belief in progress" (Thatcher 1999:27). Postmoderniteit hierteenoor is:"marked by a plurality of voices vying for the right to reality" (Middleton \& Walsh 1995:13). Van Aarde (2003:30) is verder oortuig daarvan dat postmoderniteit nie, soos sommige wetenskaplikes beweer, lei tot absolute relativisme nie, omdat absolute relativisme net soos 'n ondubbelsinnige totaliteit eintlik nie moontlik is nie. Die wegdoen van sosiaal gekonstrueerde totaliteite ontneem vermeende sekerhede. So 'n ideologieskritiese hermeneutiek kan 'n positiewe bydrae maak deur ons moderne, "absolute" sienings van die huwelik krities in oënskou te neem. Die les wat postmoderniteit 'n mens leer, is dat ons nie die korrektheid of die steekhoudendheid van ons denke kan waarborg deur van die regte metode gebruik te maak of van die regte punt af te begin, of dalk glad nie te begin nie.

\footnotetext{
${ }^{2}$ Thatcher, A 1999. Marriage after modernity: Christian marriage in postmodern times. England: Sheffield Academic Press. (Studies in Theology and Sexuality 3.)
} 
Die huwelik is nie 'n moderne of postmoderne konsep nie, maar bestaan reeds in die premoderne era. Sedert die Christelike era het baie veranderinge plaasgevind. Garton (2004:48-49) stel dit soos volg:

Did the coming of the Christian era two thousand years ago usher in a new period of sexual austerity? Did the Christian emphasis on celibacy and sex within marriage represent a clear break with the pagan ethics of the "uses of pleasure"? Common sense might suggest that Christianity was a decisive rupture with the past, but scholars disagree over the differences between the pagan and Christian sexual cultures of late antiquity. While most accept then an emphasis on sexual fidelity and monogamy within marriage, and an idealization of chastity and Christian renunciation, marked the early centuries of the Christian era, there is little agreement over the importance of Christianity in these shifts.

Modernisme het eweneens soveel sosiale veranderinge gebring dat dit noodwendig ook perspektiewe oor die huwelik positief en negatief verander het. Thatcher (1999:29) meen dat, ten spyte van die negatiwiteit rondom die Christendom in die postmoderne era, dit wel 'n nuwe geleentheid skep vir Christelike denke en praktyk: "Theology is still able to earn a hearing, insofar as it speaks positively and meaningfully to people's experience" (Thatcher 1999:30).

Thatcher (1999) bespreek in sy boek die relevansie van die Bybelse perspektiewe op die huwelik in die postmoderne era. Hy bied 'n nuttige raamwerk om die gesprek oor die huwelik binne bepaalde kontoere te laat plaasvind. Hierdie ondersoek is 'n poging om, aan die hand van sy boek, asook deur middel van ' $n$ meer uitgebreide literatuurstudie, relevante bronne te ontgin met die oog op 'n nuwe verstaan van die huwelik in 'n postmoderne era.

\subsection{Navorsingsmetodiek}

In die navorsing word die boek van Thatcher (1999) as basis gebruik, gesien die breë oorsig van relevante temas wat met die huwelik verband hou. Vanuit 'n hermeneutiese vertrekpunt wat die Bybelse konteks, die tradisie en die hedendaagse omstandighede verdiskonteer, probeer hy om op 'n verantwoorde wyse bogenoemde vraagstelling te belig. In die loop van die ondersoek word ander bronne bygewerk om 'n verskeidenheid aksente in die diskoers oor die huwelik aan die orde te stel. Die bronne word in kritiese gesprek met mekaar hanteer en, waar nodig, geëvalueer. Vanuit hierdie literatuurondersoek word die problematiek beskryf. In 'n opvolgartikel sal die 
resultate van die ondersoek verwerk word in moontlike voorstelle vir 'n nuwe verstaan van die huwelik in 'n postmoderne era.

\section{IN GESPREK MET "MARRIAGE AFTER MODERNITY"}

Thatcher begin in sy eerste hoofstuk die problematiek van die beskouing van die huwelik in die moderne era te verduidelik deur aan te dui watter metode hy gaan volg in die res van sy bespreking oor die huwelik. Hy is van mening dat 'n volledige teologie van die huwelik waarskynlik nooit geskryf kan word nie. Die gaping tussen bestaande teologiese teorieë en die praxis is so groot dat dit teologiese refleksie bemoeilik, omdat daar uiteenlopende interpretasies bestaan. Tog pak Thatcher wel die moeilike taak aan om 'n studie in hierdie veld te doen. Hy stel dit vooraf duidelik dat navorsing in die algemeen, en in die besonder, ook die studie wat hy in sy boek doen, noodwendig gepaard gaan met sekere vooronderstellings.

Hy stel ses basiese uitgangspunte wat in sy ondersoek as vertrekpunte geld: lojaliteit teenoor Jesus Christus, die Bybel, tradisie, ervaring, kultuur, en die mense van God (Thatcher 1999:12). Bo alles is lojaliteit of getrouheid teenoor Jesus Christus wesenlik: "... no other theological source has the claim on us that Christ has, whether this be Bible, creed, tradition or church" (Thatcher 1999:13). Rogers ${ }^{3}$ (2006:55) beklemtoon ook die feit dat Jesus Christus die belangrikste hermeneutiese sleutel is vir die interpretasie van die Bybel. Stephen Barton (1996:4-13) gebruik die beeld van 'n simfonie-orkes om Bybelse getrouheid te definieer. Hy vra twee belangrike vrae: Watter tipe mense moet ons wees of word om die Bybel te lees sodat dit betekenisvol is oor onderwerpe soos geslag en seksualiteit? Is die Bybel dalk soos 'n simfonie-opvoering waar die betekenis van die teks tot 'n mate sal verskil, afhangende van die mense wat optree en die omstandighede rondom die optrede?

Thatcher gebruik dieselfde metode van interpretasie in sy "teologiese hermeneutiek". ${ }^{4}$ Die probleem lê, volgens hom, nie by die Bybel nie, maar by

\footnotetext{
${ }^{3}$ Jack Rogers is ' $n$ hetroseksuele man en predikant in die Presbiteriaanse Kerk in die VSA. As moderator en voorsitter van sy kerk se studiekomitee oor homoseksualiteit het hy sterk leiding geneem. Hy sê dat hierdie ondersoek daartoe bygedra het dat hy van sy tradisionele en rigiede oortuigings oor seksualiteit afskeid moes geneem het. Hy het sy boek, Jesus the Bible and homosexuality:Explode the myths, heal the church, geskryf omdat hy glo dat daar nie meer stilgebly kan word oor die onreg wat die kerk aan seksuele minderhede gepleeg het nie. In sy boek doen hy self ondersoek oor Bybelse tekste in verband met homoseksualtieit en en neem hy 'n mens saam op sy reis om verby stereotipering te beweeg.

${ }^{4}$ Volgens Van Aarde (2005:35) is teologiese hermeneutiek of teologiese eksegese wanneer die teks gehoor word in die aktuele gehoorsaamheid aan die aanspraak van God (wat deur die menslike teks en getuienis geskied) en in die geloofsverwagting dat God in vryheid God se Woord vir ons sal open. Die leser van die Bybel moet onthou dat die kerk tot hier toe in hierdie boek die Woord van God gehoor het, en dat die kerk die verwagting sal hê om self ook hier vir die hede die Woord van God te hoor. Die plek van teologiese eksegese en hermeneutiek lê tussen hierdie herinnering en verwagting.
} 
die lesers. Die lesers moet dus soek na die interpretasie wat alle mense se lewens kan verryk en God se onvoorwaardelike liefde weerspieël (Thatcher 1999:15). Met ander woorde, 'n soeke na die simfonie van die Woord in teenstelling met die eensydige kakofonieë wat dikwels in die verlede deur hoofrolspelers laat hoor is.

Hy stel ook voor dat ons lojaliteit teenoor ons tradisie op 'n soortgelyke wyse, in die lig van lojaliteit teenoor Jesus Christus, hanteer moet word. Dit behels 'n soeke na die simfoniese klanke binne 'n tradisie wat onvoorwaardelike liefde laat opklink. Dieselfde geld ook vir lojaliteit teenoor ervaring:stemme wat in die verlede stilgemaak is, moet toegelaat word om te praat. Lojaliteit teenoor kultuur behels dat ons die moontlikheid moet insien dat die Heilige Gees wel buite die grense van die kerk om kan werk. Laastens bespreek Thatcher (1999:24) ook die gebondenheid aan die volk van God. Weer eens hoor 'n mens hierin 'n openheid en 'n bereidheid om te luister, nie net na die teoloë en ander hoofrolspelers nie, maar na alle mense van God.

In hoofstuk twee bespreek Thatcher die dialoë waarby Christene in die Postmoderne era betrokke is en moet word. Hy identifiseer twee soorte dialoë, naamlik: die interne dialoog tussen kerke; die eksterne dialoog tussen Christene en die sekulêre gemeenskap wat nie meer dink dat die Christendom relevant is nie. Beide hierdie tipes dialoog dra by tot die lewende tradisie van teologie. Ons kan ook hier 'n verdere dialoog byvoeg tussen die kerk en spirituele mense wat hulle nie noodwendig tuis voel binne die institusionele kerk nie. ${ }^{5}$

By die interne dialoog stel Thatcher problematiese vraagstukke oor die huwelik aan die orde wat bespreek sal moet word. In die eerste plek moet daar gevra word wat 'n mens moet maak met die verskeidenheid van sienings oor die huwelik binne veral die Nuwe Testament ${ }^{6}$ Kan die sienings binne die Bybel bydra tot ons kontemporêre verstaan van die huwelik? Tweedens is die vraag of die aanname dat die huwelik 'n onbreekbare en ondeelbare eenheid is, essensieel is vir die Christelike geloof, of is dit op mense afgeforseer om huwelike wat eintlik reeds ten einde geloop het in stand te hou? Verdere vraagstukke is of die huwelik bedoel is as sakrament, of nie? Hoe geldig is teologieë oor die huwelik wanneer dit hoofsaaklik gebaseer is op die ervaring

\footnotetext{
${ }^{5}$ Dit is juis die doel van publieke teologie om ons in aanraking met hierdie mense te bring. Dit sal alleen moontlik wees om in dialoog met hierdie persone te tree as die kerk nie aan die status quo vasklem nie, maar daarna streef om hervormend te wees. Daar sal nuut gedink moet word oor die term "eenheid" en of hierdie term "eendersheid" veronderstel en of "andersheid" geakkommodeer kan word. Anders is die dialoog nutteloos.

${ }^{6}$ Dreyer (2006:1293) meen dat diversiteit en verskeidenheid nie negatief hoef in te werk op die kerk nie. Diversiteit in die kerk en spesifiek $\mathrm{m}$ b t die huwelik is 'n gegewene, en die energie wat daaruit voortvloei kan tot voordeel van die kerk bestuur word in die postmoderne samelewing. "Eenheid in verskeidenheid" is hier die slagspreuk.
} 
van mans? En laastens, is 'n nie-patriargale huwelik as instelling 'n sosiale moontlikheid?

Buiten die interne dialoog is daar ook die eksterne dialoog wat moet plaasvind tussen die Christelike tradisie en dié wat dit gedeeltelik of in die geheel verwerp. Vir Thatcher (1999:31) is die eksterne dialoog nog meer van belang as die interne. Hy noem 10 algemene kenmerke van 'n postChristelike seksuele etiek, maar voeg ook Christelike alternatiewe op hierdie tipe etiek by. Thatcher (1999:64) stel dit soos volg in tabelvorm voor:

\begin{tabular}{|l|l|}
\hline Postmoderne benaderings tot die huwelik & Christelike benaderings tot die huwelik \\
\hline 1. die marginalisering van die huwelik & $\begin{array}{l}\text { 1. die sentraliteit van die huwelik as die } \\
\text { waarde van wedersydse } \\
\text { selfopoffering }\end{array}$ \\
\hline $\begin{array}{l}\text { 2. die ontruiming van die tradisionele } \\
\text { betekenisse van die huwelik }\end{array}$ & $\begin{array}{l}\text { 2. die herwinning van die tradisionele } \\
\text { betekenisse van die huwelik, kinders, } \\
\text { getrouheid, sakramentaliteit }\end{array}$ \\
\hline $\begin{array}{l}\text { 3. die afwesigheid van kinders } \\
\text { 4. 'n individualistiese siening van die } \\
\text { mens as persoon }\end{array}$ & $\begin{array}{l}\text { 3. kinders as God se seën op die } \\
\text { huwelik }\end{array}$ \\
\hline $\begin{array}{l}\text { 5. 'n vereriale siening van die mens as } \\
\text { person-in-relasie }\end{array}$ \\
\hline $\begin{array}{l}\text { 6. 'n persoonlike identiteit as 'n } \\
\text { lewenslange strewe }\end{array}$ & $\begin{array}{l}\text { 5. 'n God-mens liefde gegrond in die } \\
\text { goddelike Triniteit }\end{array}$ \\
\hline $\begin{array}{l}\text { 7. die oppervlakkigheid van 'n sekulêre, } \\
\text { post-tradisionele etiek }\end{array}$ & $\begin{array}{l}\text { 6. 'n Christelike identiteit verkry deur 'n } \\
\text { verhouding met ander te deel } \\
\text { "passievolle etiek": die } \\
\text { gemeenskaplike karakter van } \\
\text { moraliteit }\end{array}$ \\
\hline $\begin{array}{l}\text { 8. die tradisie van laat sekulêre } \\
\text { humanisme }\end{array}$ & $\begin{array}{l}\text { 8. die herwinning van die historiese, } \\
\text { ontwikkelende, Christelike tradisie }\end{array}$ \\
\hline $\begin{array}{l}\text { 9. kortstondige seksuele verhoudings } \\
\text { 9. 'n lewenslange verbond met een } \\
\text { persoon }\end{array}$ \\
\hline $\begin{array}{l}\text { 10. 'n post-patriargale, post-religieuse } \\
\text { etos }\end{array}$ & $\begin{array}{l}\text { 10. 'n post-patriargale, outentieke } \\
\text { religieuse etos }\end{array}$ \\
\hline
\end{tabular}

In hoofstuk 3 ondersoek Thatcher die Bybel om te verduidelik hoe hy by die bogenoemde Christelike alternatiewe uitkom.

\section{BYBELSE MODELLE VAN DIE HUWELIK}

Indien daar gekies word vir 'n hermeneutiese benadering kan daar nie net eenvoudig met bepaalde tekste in isolasie omgegaan word nie. Die interpretasie van elke teks word mede-bepaal deur die konteks waarin dit afspeel. Thatcher is dus korrek in sy benadering dat daar nie net 'n enkelvoudige perspektief op die huwelik in die Bybel te vind is nie, maar dat 'n 
mens binne verskillende kontekste telkens weer ander perspektiewe op die huwelik vind. Daarom identifiseer hy verskillende "modelle" wat in die Bybel aangetref word en wat ons kan help om vir ons eie tyd sekere kontoere vir die huwelik te trek.

Eerstens word daar in die ondersoek gefokus op die onderskeie "modelle" wat Thatcher (1999:67) aandui. Later sal gepoog word om die relevansie van daardie "modelle" vir vandag aan te dui. Hy verkies om die woord "model" te gebruik, omdat 'n model nooit gelykstaande is aan wat dit voorstel nie. Die model is maar 'n klein gedeelte van die groter realiteit. Hy noem twee hoofmodelle en drie alternatiewe modelle van die huwelik wat 'n mens in die Bybel kry. Die hoofmodelle is die "verbond" asook die model van "eenwording", terwyl die sekondêre modelle "twyfelagtige noodsaaklikheid", "wêreldse vergunning" en "passievolle wedersydse liefde" is.

\section{1 'n Verbond}

Volgens Anderson (1993:138) is 'n verbond 'n toegewyde verhouding, wat beide beloftes en verpligtinge insluit en gewoonlik deur 'n ritueel verseël word. Palmer (1972:618) maak verder onderskeid tussen 'n verbond en 'n kontrak. 'n Kontrak het mense as getuies en versekering, terwyl God of gode hierdie funksie by ' $n$ verbond vervul. In die geval van die huwelik as 'n verbond, is seksuele omgang deur sommige Bybelskrywers gesien as "... a complimentary covenant-ratifying oath-sign ... " en was dit, veral in die ou Nabye Ooste en die Ou Testament ".... the indespensable means for the consummation of marriage ..." (Hugenberger 1994:343).

' $n$ Verdere belangrike kenmerk van 'n verbond is die ongelyke verhouding tussen die twee partye. Hier kan byvoorbeeld die verhouding tussen God en die volk van God genoem word, waar God altyd getrou aan God se verbond bly, terwyl die volk ontrou en ongehoorsaam is. In die antieke tyd is 'n verbond meestal gesluit tussen 'n koning en sy onderdane. Later het 'n verbond kenmerkend geword van goddelike liefde en trou.

Om die verbondsmodel by die huwelik te gebruik, klink aanvanklik belowend, omdat dit gebaseer is op die verhouding tussen God en die geloofsgemeenskap, maar so 'n ongelyke verbondsverhouding kan ook baie problematies wees omdat 'n verbondsverhouding 'n ongelyke verhouding veronderstel. Thatcher (1999:69) meen dit veroorsaak dat vroue gestereotipeer word as "... inferior and unfaithful partners ... " Dit is nodig om op hierdie punt onderskeid te maak tussen twee strome binne die Reformatoriese teologie wat twee verskillende Latynse woorde vir "verbond" gebruik het. Die eerste is die term "foedus" wat beklemtoon is deur die Zürichse Hervormers, insluitend Zwingli en Bullinger. Wanneer "foedus" as die 
vertaling van verbond gebruik word, veronderstel dit 'n bilaterale verhouding:'n ongelyke verhouding waar God die inisiatief neem, maar waar die mens ook keuses kan maak. "Testamentum" is die Latynse woord vir verbond wat veral deur Calvyn gebruik is, en ' $n$ verhouding veronderstel waar God eensydig inisiatief neem en die mens eintlik geen keuse het nie. Calvyn kies hierdie term omdat dit gegrond is op sy siening van die uitverkiesing. ${ }^{7}$ Volgens Ford (1984:27-31) het Karl Barth die "verbond" op die huwelik toegepas en ook in die "hiërargiese" strik geval om die vrou in hierdie "verbondsverhouding" op 'n subordinasie-vlak te plaas, omdat die verbond tussen God en mens per definisie op 'n ongelyke verhouding neerkom.

In die boek Hosea, word Hosea se huwelik met die ontroue Gomer gebruik as 'n model vir die gebroke verbond tussen God en die volk. Liefde en vergewing speel hier ' $n$ belangriker rol as wette en geregtigheid wanneer Hosea sy vrou vergewe en terugneem, en so ook God die volk Israel. Daar is egter weer eens die probleem van 'n ongelyke verhouding, want alle seggenskap lê by die Goddelike party. Na analogie van die verbondsverhouding tussen God en die volk, stel die man God voor, terwyl die vrou God se ongehoorsame volk is. Verder kry 'n mens in hierdie vergelyking met Hosea en Gomer verwysings na seksuele geweld wat Hosea sal gebruik om sy vrou terug te kry. Weems (1989:101) wys uit dat dit vir vroue wat slagoffers was van seksuele geweld, ' $n$ ondraaglike metafoor is om God voor te stel as 'n woedende eggenoot. ${ }^{8}$

Jeremia en Esegiël gebruik ook 'n gebroke huwelik om die verhouding tussen God en die volk voor te stel. Thatcher (1994:72) beklemtoon hier veral die feit dat God die een is wat die egskeiding inisieer. Hy identifiseer ook verskeie stereotiperings wat deur hierdie teksgedeeltes gekondoneer word, en kom daarom tot die gevolgtrekking dat hierdie verbondsmodel nie net so in 'n Christelike huwelik gebruik kan word nie.

... women can't be trusted; women are naturally randy and unfaithful; prostitutes like sex; women's beauty is a source of sin; women deserve violence and humiliation as legitimate punishment. Even the depiction of a fresh start, the new covenant, will induce a

\footnotetext{
${ }^{7}$ Vgl Milner, B C 1970. Calvin's doctrine of the church. Leiden:Brill; op grond van Calvyn, Inst II.10.

${ }^{8}$ Die "probleem" is nog groter: Hosea word dikwels as interteks vir Efesiërs (veral hoofstukke 3 en 5) gesien. Wolff (1974:204) praat van "paradigmatiese betekenis". In Efesiërs 5 het ons ongetwyfeld met die ondergeskiktheid van die vrou aan die man as hoof ( $\kappa \varepsilon \phi \propto \lambda \varepsilon \dot{\varepsilon}$ te doen. Naas seksuele geweld in Hosea, het ons ook die vrugbaarheidsgodsdiens as grondliggende bedding van Hosea se "huweliksmetafoor"-teologie (vgl May, H G 1932. The fertility cult in Hosea. American Journal of Semitic Languages and Literatures 48, 73-89).
} 
state of disabling female guilt, the weight of which renders women dumb and makes mutual participation in the covenant impossible ...

(Thatcher 1994:73)

In Deutero-Jesaja verskuif die beeld van God as die man in 'n huweliksverbond, deurdat God nie geaffekteer word deur die ontrou van mense nie, en dat God nooit God se verbond sal verbreek nie.

Maleagi se siening van die huwelik as verbond, is, volgens Thatcher (1999:75) “... unsurpassed in the Hebrew Scriptures." Maleagi praat vir die eerste keer van individuele huwelike in Israelitiese konteks as 'n verbond. Daarom word hy ook kwaad vir die Israelitiese mans omdat hulle van hulle vroue skei om met heidense vroue te trou. ${ }^{9}$ Deur dit te doen, verbreek hulle die verbondsolidariteit met God as die Vader van mans èn vroue. Die verbreking van die huweliksverbond word verbind met die verbreking van die verbond met God. Dit het sodoende implikasies vir die hele volk en nie net vir individue wat skei nie. Maleagi beoordeel egskeiding as verkeerd, omdat dit selfsugtig is en "... because it involves the exercise of unequal power of men over women ... " (Thatcher 1999:74). Die Ou Testament gebruik die "verbond" tussen God en Israel as 'n metafoor om die verhouding tussen die bruidbruidegom te verduidelik. Dit word ook in 'n sekere sin in die Nuwe Testament gekontinueer as daar na Christus as die bruidegom en die kerk as sy bruid verwys word. Hierdie verhouding tussen Christus en sy kerk word ook toegepas op die verhouding tussen man en vrou.

Dit is veral die uitsprake in die Deutro-Pauliniese boek, Efesiërs, en hoofsaaklik in hoofstuk 5, wat 'n bepaalde perspektief op die huwelik as ' $n$ "verbondsverhouding" bied. Daar word nie na die term verbond verwys nie, maar ons kry wel verwysings na die term van "offer" wat met ' $n$ verbond te make het asook na standhoudende wederkerige liefde wat die kenmerkende is van 'n verhouding. In Efesiërs het ons te make met een van die sogenaamde huistafels in die Nuwe Testament, wat die bekende analogie van Jesus en die kerk met die verhouding van man en vrou bevat. Alhoewel daar die oproep is dat Christene aan mekaar onderdanig moet wees, beteken dit nie dat vroue en mans nou gelyke status het nie. Inteendeel, onderdanigheid aan die man word nou ' $n$ "teologiese rasionaal" gegee. Omdat die vrou aan haar man onderdanig moet wees soos die kerk aan Christus, kry die ondergeskiktheid van die vrou nou goddelike sanksionering. Hy begrond hierdie oproep gewoon in die aanvaarde sosiale stratifikasie van sy tyd,

\footnotetext{
${ }^{9}$ Bosman (1979:32-38) verduidelik hierdie praktyk in sy artikel oor die huwelikshervorming by Esra.
} 
naamlik dat die man as hoof van die vrou beskou is. As 'n mens hierdie analogie verder deurtrek, is die man die redder van die vrou soos Jesus die Redder van die kerk is. Volgens Stegemann en Stegemann (1999:404) word die patriargale oorheersing van die man oor die vrou nie verander deur dit met die verhouding van Christus te vergelyk nie. Daar word wel 'n resiproke uitdaging aan die man gerig om sy oorheersing te beperk.

Tog kom hier 'n nuwe perspektief na vore. ${ }^{10}$ Mans word nou opgeroep om hulle vroue lief te hê en "... to give themselves to their wives with all the devotion and totality with which Christ gave Himself to the Church" (Thatcher 1999:77). Die Bruid van Christus word ook deur Hom geheilig, en niks verder is nodig om haar 'n aanvaarbare bruid te maak nie. Christus het Homself, deur sy offer, ${ }^{11}$ onherroeplik met die kerk verenig, daarom moet mans hulle vroue ook so liefhê. In die lig hiervan moet 'n mens toegee dat die outeur tog probeer het om die huweliksverhouding van 'n Christelik-etiese karakter te voorsien. Die ondergeskikte lede van die familie, kry nou ook 'n belangrike rol om te speel en word volgens Osiek (2006) as persone in eie reg aangespreek. Van Aarde (2002:102) meen egter dat 'n mens nie 'n werklik bruikbare huweliksetiek op hierdie perikoop kan bou nie, omdat die outeur nie probeer het om die situasie van die vrou grondig te verander nie.

Tog dink ek dat daar in hierdie gedeelte wel iets na vore kom wat die tradisionele patriargale huweliksverhouding ten minste in 'n ander lig stel. Dit is byvoorbeeld ondenkbaar dat in 'n patriargale verhouding, waar die vrou bloot as besitting beskou is, daar van mans vereis word dat hulle hulle vroue moet liefhê. Dieselfde nuwe gedagte kom na vore in die eis dat hulle aan mekaar onderdanig moet wees. Die onderdanigheid van die man in 'n patriargale verhouding gaan teen die grein van die destydse samelewing in. Die teenhanger van die onderwerpingsgebod in Efesiërs 5:22-24 is dus nie om vir die mans 'n aanwysing tot oorheersing te gee, soos wat 'n mens sal verwag van 'n patriargale sisteem nie, maar tot selfprysgewende liefde. Osiek (2006) noem dit "an articulated ideal of mutual submission." Tog meen sy dat gelowiges die boodskap in hierdie gedeeltes anders gehoor het: "the well-run household is the foundation of society, and well-run means maintaining the

\footnotetext{
${ }^{10}$ Karl Barth oordeel dat dit nie so "nuut" is nie. In sy motief "analogia relationis" (Karl Barth, $K D$ II.1.207-220) sien hy die analogie in Efesiërs met God se konstante liefde waarvan die profete praat, ten spyte van die ontrou van Israel. Hy handhaaf egter 'n subordinasie van die vrou aan die man in die huwelik op grond van Matt 19:4-5 en Ef 5:31 na aanleiding van Gen 1:27 en Gen 2:24 (kyk o a Berkouwer [1962] 1968:72-74, 89-100).

${ }^{11}$ Dit is egter ' $n$ vraag of hiermee dieselfde bedoel word as wat Paulus onder "offer" verstaan het, naamlik die soeningsdood van Jesus. Die uitkoms by Efesiërs blyk nie soos by Paulus ' $n$ sterwe saam met Christus te wees nie en is steeds 'n eksegetiese probleem (vgl Van Aarde, A G 2002. Gevorderde studie van inleidingsvraagstukke van die Pauliniese korpus. Module 453, Nuwe-Testamentiese Wetenskap, bl 85.
} 
hierarchical structure that had always been the philosophical and political ideal." Dit is weliswaar so dat hierdie dimensie oor die huwelik in die Pauliniese en Deutero-Pauliniese tradisie deur die kerk ook so vertolk is dat dit die tradisionele patriargale patroon ondersteun het. Dit bevestig die feit dat kulturele waardes 'n deurslaggewende rol in Bybelinterpretasie gespeel het en steeds speel.

\section{2 "Vleeslike" eenwording}

Hierdie model kan teruggevind word in Genesis 2:23-24. Veral die redaksionele opmerking van vers 24 is belangrik: "Daarom sal 'n man sy vader en moeder verlaat en saam met sy vrou lewe, en hulle sal een word" (Gen 2:24). Dit word "eenheid van die vlees" genoem omdat dit oorspronklik kom van die metafoor dat die vrou vanuit die vlees van die man gevorm is. Dit het ook te doen met seksuele gemeenskap. Die twee, man en vrou, word 'n totale nuwe eenheid. In die Ou Testament kom hierdie model, behalwe vir hierdie gedeelte in Genesis, nie weer voor nie (Thatcher 1999:78). Volgens Le Roux (2006:28) moet ons egter nie die fout maak om te dink dat die Ou Testament liggaam, siel en gees van mekaar geskei het nie. Eenwording omvat die totale mens.

In die Evangelie van Markus haal Jesus self hierdie gedeelte uit Genesis aan, met die verdere opmerking dat die man en vrou na eenwording nie meer twee individue is nie, maar een vlees, en omdat God dit saamgevoeg het, mag niemand dit skei nie (Mark 10:8-9). Markus 10:5-9 handel oor Jesus se antwoord op die vraag van die Fariseërs oor 'n aanvaarde gebruik in sy tyd, te wete dat ' $n$ man, op grond van Deuteronomium 24:1, van sy vrou kan skei deur aan haar 'n skeibrief te gee. Hierdie is 'n ontsettende gekompliseerde teks waaroor wetenskaplikes dikwels verskil. Oor hierdie problematiek sê Donahue en Harrington (2002:298) dat ' $n$ mens nie moet toelaat dat dit die betekenis van "eenheid van vlees", waarop Jesus klem lê, vergeet nie:

Recognition of the complexities involved in the NT evidence about marriage and divorce should not be allowed to obscure the positive character of Jesus' teaching about husband and wife constituting "one flesh". This teaching must be placed in the context of Jesus' proclamation of God's kingdom and the radical demands it may make on people. On the one hand Jesus has a vision of restored creation in which unity and mutuality in marriage mirror God's original plan. 
On the other hand Jesus summons men and women to a discipleship that recognizes the radical demands of God by precluding divorce just as in some cases it may preclude marriage.

Daar sal later oor egskeiding op sigself gehandel word, maar nou wil ek eers net fokus op die "een in vlees" opmerking van Jesus. Hierdie uitspraak van Jesus het geweldige implikasies. Jesus se interpretasie van Genesis 1:27 en Genesis 2:24 is volgens Van Eck (2006:4-5) dat die man en vrou gemaak is om bymekaar te wees. In die geval van 'n huwelik behoort die man sy vader en moeder te verlaat, en man en vrou behoort een te wees, nie twee nie. Die "eenheid van vlees" veronderstel 'n persoonlike eenheid wat aan beide man en vrou 'n nuwe identiteit verleen, sodat die een party, wie hy of sy is, in relasie met die ander party is. Daarom is hierdie relasie ook permanent. Donahue en Harrington (2002:294) sê hieroor: "According to the logic of Mark 10:6-9 the original will of God in creating man and woman was that they should constitute 'one flesh' in an indissoluble union." God is hier nie net die getuie by eenwording nie, maar die Een wat dit bekragtig, wat dit so "gewil" het. Dit maak dat egskeiding en poligamie dus nie geregverdig kan wees nie (Thatcher 1999:79-80). Volgens Donahue en Harrington ( 2002:294) stel hierdie eenheid in vlees eintlik die hereniging voor van waar die vrou in Genesis 2 uit die man se rib geneem is.

Volgens Paulus is hierdie "eenheid van vlees" 'n rede waarom Christen-mans nie met prostitute omgang mag hê nie. Dit klink vreemd, maar Paulus gebruik eintlik dieselfde argument as Jesus. Omdat man en vrou een geword het, en nie meer twee individue is nie, is hulle deel van mekaar, hulle behoort aan mekaar. "The unity which they make as a couple vetoes any sexual independence which they may once have had as single people" (Thatcher 1999:80). Donahue en Harrington (2002:297) dink egter nie dat Paulus dieselfde gedagte as Jesus gehad het nie, omdat Paulus die uitsluitingsklousule van Matteus 5:32 en 19:9 byvoeg by sy raad vir Christene in gemengde huwelike. Beide die vroeë kerk en die Joodse tradisie het 'n ongemak met Jesus gehad.

Efesiërs neem vleeslike eenwording 'n stappie verder deur te sê dat 'n man, deur sy vrou lief te hê, ook homself liefhet. Hierdie twee liggame wat een geword het, behoort nie net aan mekaar nie, maar die twee mense is ook mekaar! "Self"-liefde kry dus in die Christelike huwelik 'n nuwe betekenis. Die self kan net tot sy reg kom in die verhouding met die ander. So kry die getroude persoon dus 'n nuwe identiteit. Volgens King (2006:364) kry ons in Hooglied dieselfde idee van eenwording en 'n nuwe identiteit: "The lovers' mutual exchange of desires, then, becomes a mutual gift of selfhood. Not only 
do the Shulamite and the Beloved give themselves to the other without holding back; they also each recieve their own new and truest identity from the other's gift of desire ...." Die skrywer van Efesiërs voeg ook sy eie kommentaar op Genesis 2:4 by: "Hierin lê daar 'n diep "geheimenis"12 opgesluit, en ek pas dit toe op Christus en die kerk" (Ef 5:32). Die skrywer van Efesiërs probeer dus die Genesis teks versigtig Christelik toepas. "Christ's love is thought to exemplify the love which the writer believes is to be found in the one-flesh union of Genesis" (Thatcher 1999:81). ${ }^{13}$

\section{3 'n Twyfelagtige noodsaaklikheid}

In die Hebreeuse wysheidsliteratuur vind ons 'n ander model vir die huwelik wat wissel tussen waardering van die huwelik en agterdog daaroor. In hierdie geskrifte is vroue sonder uitsondering vanuit 'n androsentriese perspektief almal dieselfde:die objekte van passie, bewondering, sorg en dankbaarheid, maar ook van agterdog en haat. Machin (1989:50) stel dit soos volg:

"Husbands are warned repeatedly against the other woman's allure. No wife is ever warned about a husband's fragile fidelity".

Volgens hierdie model is 'n vrou noodsaaklik vir 'n man om ryk, suksesvol en gelukkig te wees, met 'n lang en goedversorgde lewe. Spreuke sê byvoorbeeld dat knap vroue, letterlik gesien, baie werd is. Hulle waarde word selfs meer as dié van edelstene geskat (Spr 31:10). Thatcher (1999:82) maak egter die afleiding dat "... a marriage is a source of blessing for the husband, it is also a source of grief for him. While a wife is a necessity, she is a dubious one." Tog is daar in Spreuke, volgens Stuart (2006:327), iets of iemand wat vreemd is in terme van die patriargale samelewing, naamlik, "Sophia" of "Hochma" of "Wysheid": "Here we are presented with a female figure who is somehow with the Lord at the beginning, somehow brought forth before creation and somehow coexisting with him like a child or master workman, seperate and yet intimately connected." Die patriargale konteks van Spreuke 1-9 toon egter duidelik dat die manier waarop die stem van "Wysheid" geposisioneer word die patriargale sisteem ondersteun het.

\footnotetext{
${ }^{12}$ Hier het ons die grond van die Rooms-Katolieke Kerk se "sakramentalisering" van die

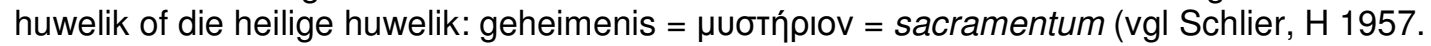
Der Brief an die Epheser. Düsseldorf:Patmos-Verlag, 264-276).

${ }^{13}$ Karl Barth (KD II.1.207-220) het in sy eksegese van Efesiërs 5 en Genesis 1 en 2 tot sy idee van selfverwesenliking van die mens in die huwelik gekom. Volgens hom is dit die sogenaamde "analogia relationis". Dit is die verhouding vna die Skeppergod met die mens as verbonds-"partner" (vgl ook voetnota 10).
} 


\section{Bybelse modelle van die huwelik: 'n Kritiese perspektief}

Die boek Prediker, met sy kritiese ingesteldheid teenoor konvensionele wysheid $^{14}$ en sy oënskynlike pessimisme oor die lewe, bring verrassend genoeg 'n meer positiewe nuanse na vore. Le Roux (2006:33-34) stel dit interessant:"In elke poging om hierdie onaf lewe mooi te maak, was die vrou, die lyf onontbeerlik. In die oordaad van die liefdesgenot word die lewe se sinloosheid ver ente teruggestoot. In die intense lewenservaring kiem 'n nuwe lewenssin. In die naby-ervaring van die ander word nuwe lewensmoontlikhede ontsluit." Volgens Barth (1961:383-402) beteken dit dat die lyf se genot voluit geniet moes word omdat die lewe nie sinvol sluit nie. Dit was 'n manier om sinloosheid te hanteer. Tog is Prediker se nuanse ook maar gekleurd deur 'n androsentriese perspektief waar alleen mans seksuele genot kan ervaar. So byvoorbeeld was vroulike besnydenis algemeen in die Meditereense kultuur, en is die klitoris verwyder om orgasmes by vroue te voorkom. ${ }^{15}$ Koosed (2006:353) glo egter steeds dat Prediker 'n ander perspektief toon as die tradisionele: "What else besides 'queer' would you call someone who opposes the traditional platitudes about God and the social order, and instead wants to replace such traditional piety with a good party; someone who thinks that one should pay proper attention to dressing well, styling one's hair, and smelling good?"

\section{4 'n Wêreldse vergunning}

In 1 Korintiërs 7 gee Paulus 'n meestal negatiewe beeld van die huwelik weer. Die huwelik is alleenlik ' $n$ toegewing wat gemaak word om immorele optrede soos seksuele omgang buite die huwelik te vermy. Boonop is dit beter om ongetroud te bly, omdat die huwelik die teken is van wêreldsheid en dit 'n mens se aandag aftrek van die Here se werk. Die huwelik is dus toelaatbaar, maar nie aanbevole nie. Botha (2006:125) sê dat Paulus hier hoofsaaklik gekant is teen begeerte omdat begeerte en seks saam sondig is. Seksuele omgang kan soms nodig wees, maar dan moet dit sonder hartstog en drif wees. Volgens Thatcher (1999:84) was dit die siening wat vir meer as 'n millennium in die Christelike kerk gehandhaaf is.

Tog is 'n ander kenmerk van Paulus se siening van die huwelik dikwels misgekyk:

\footnotetext{
${ }^{14}$ Vergelyk onder andere Loader, J A 1979. Polar structures in the book of Qohelet. Berlin: De Gruyter, bls 117-123.

${ }^{i 5}$ Kyk onder andere Trible, P 1984. Texts of terror: Literary feminist readings of Biblical narratives. Philedelphia, PA: Fortress; Tatman, L 1998. The yearning to be whole-enough or to feel something, not nothing: A feminist theological consideration of self-mutilation as an act of atonement. Feminist Theology 17, 24-38.
} 
${ }^{3}$ Die man moet sy huweliksplig teenoor sy vrou nakom, en net so ook die vrou teenoor haar man. ${ }^{4}$ Die vrou beskik nie oor haar eie liggaam nie, maar die man; net so beskik die man ook nie oor sy eie liggaam nie, maar die vrou. ${ }^{5}$ Moenie vir mekaar omgang weier nie, behalwe met wedersydse toestemming en net vir 'n bepaalde tyd om julle aan die gebed te wy.

(1 Kor 7:3-5a)

Dit is duidelik vanuit hierdie aanhaling dat Paulus die man en vrou as gelyke vennote binne die huwelik, veral op die liggaamlike vlak, gesien het.

In Matteus en veral Lukas is die huwelik in 'n selfs meer negatiewe lig as Paulus beskou. In Lukas 20:34-36 is mense wat getrou het, bewoners van hierdie wêreld en nie die toekomstige wêreld nie - hulle huwelikstatus stel eintlik hulle deelname aan die opstanding in gevaar! Volgens Lukas is hierdie 'n siening van Jesus self. Daarom moet die huwelik so ver moontlik vermy word.

Hierdie siening van seksualiteit kry ons nie in die Ou Testament nie. Volgens Groenewald (2006:56) sou die idee dat jou liggaam of seksualiteit tussen jou en God kan kom staan, 'n hindernis of vertroebeling kan veroorsaak, vir Israel absurd voorgekom het.

\subsection{Passievolle wedersydse liefde}

Die opspraakwekkende Ou-Testamentiese boek, Hooglied, is 'n voorbeeld van hierdie model. Tom Gledhill (1994) som die algemene persepsie van kommentatore oor die boek op: “... joyous, tentative explorations of love of the betrothed couple culminating in their marriage and full sexual union in 5:1."

Roland Murphy (1990:60) sê egter dat daar geen werklike basis is vir die argument dat die huwelik geïdentifiseer moet word met die agtergrond van die boek of die doel van die verskillende poëtiese eenhede nie. Dit is so dat die skrywer van die boek Hooglied nêrens werklik aandag gee aan die huwelikstatus van die paartjie nie. Volgens Viviers (2006:101) voorsien die paartjie wel 'n huwelik iewers in die toekoms, maar op die oomblik is al wat saakmaak hulle passievolle liefde vir mekaar. Viviers (2006:101) maak dit ook duidelik dat die Hooglied-skrywer nie die huwelik van destyds wou ondermyn en verwerp nie, maar dit wel wou relativeer: "Ware en getroue liefde is die belangrike saak, die ruimte waarbinne dit gebeur is onbelangrik. En dit sluit die seksuele verhouding in." Fox (1985:313-314) som Hooglied se standpunt soos volg op: "With Canticles sexual intercourse does not consummate marriage. Rather, marriage will consummate sex ..." 


\section{Bybelse modelle van die huwelik: 'n Kritiese perspektief}

Dit is opmerklik dat die vrou die eerste aan die woord kom in 1:2. Sy vertel in kleurryke taal en meer dikwels as die man van haar vrese, drange en behoeftes. Sy is die een wat haar geliefde uitnooi tot intimiteit en meestal neem sy self die inisiatief (Gledhill 1994:93). So word die asimmetriese verhouding tussen man en vrou, wat veral in die verbond voorgekom het, op 'n subtiele manier ondermyn. Gledhill (1994:140) dink ook nie hierdie vreemde simmetrie is baie diep versteek nie: "This reciprocity, this mutuality is something that shines out from the Song, something of a protest against the male dominance and macho-masculinity which sin brought into the world". As gevolg hiervan meen sommige selfs, soos LaCoque (1998:62) dat die boek Hooglied deur 'n vroulike outeur of outeurs geskryf is.

King (2006:363) beklemtoon die feit dat die paartjie nie hul identiteit as man of vrou verloor nie, maar dat die boek Hooglied weier om aan hierdie verskil absolute sosiale, morele of metafisiese belangrikheid te verleen. Daarom glo hy dat die teks die liefdesverhouding suiwer van die verabsolutering van 'n hiërargie tussen man en vrou en die verskille in mag, tipies van die tradisionele verhoudings tussen mans en vroue.

Die paartjie se genot en vreugde word genoem sonder verdere verwysing na die verwekking van kinders of om God te behaag. Temas soos vrugbaarheid en voortplanting wat so dikwels in ander Ou-Testamentiese boeke voorkom, vind ons skaars in Hooglied. Geliefdes gee hulleself aan mekaar in totale toewyding. Die man en vrou vertel beide van die bevrediging en genot wat hulle in mekaar gevind het. Skoonheid word ook nie soos in die boek Esegiël deur die man aan die vrou oorgedra nie, in Hooglied word die vrou geprys oor hoe sy reeds is (Thatcher 1999:87).

Tog kan selfs die geliefdes van Hooglied nie die donker wolk van die onderdrukkende kultuur van die tyd ontsnap nie. Volgens King (2006:365) het die vrywillige prysgewing van hulle verskille in status en mag ook 'n negatiewe gevolg: “... in the course of eschewing difference, they have made themselves 'different' - deviant - in the public eye. Pursuing a vision of equality in desire and reciprocal self-offering, they have made themselves vulnerable to exclusion as outsiders, as 'queers'." Hulle optrede het die Israelitiese siening van respektabelheid ondermyn omdat hulle onder andere die geslagspesifieke grense en karaktertrekke oorskry het. Waar die vrou byvoorbeeld as karaktertrek passief moes wees, neem sy dikwels inisiatief en waar die man in as karaktertrek in beheer moes bly, verloor hy dikwels beheer. ${ }^{16}$

\footnotetext{
${ }^{16}$ Vergelyk Stegemann E W \& Stegeman W 1999. The Jesus Movement: A social history of its first century, 361-377. Edenburgh: T \& T Clark.
} 


\subsection{Samevattende opmerking}

Hierdie oorsig oor die verskillende modelle wat Thatcher onderskei help die navorser om die verskillende aksente van die huwelik, soos dit in die gang van die geskiedenis ontplooi het, te verstaan. Uiteraard kan die modelle nie net so regstreeks vir vandag as norm vir die huwelik gebruik word nie, maar binne die konteks van vandag sal dit oorweeg moet word watter bydra hierdie modelle kan lewer.

\section{KOMMENTAAR OP THATCHER SE MODELLE}

Thatcher gebruik modelle om die saak van die huwelik te onderskei van die vorm wat dit aangeneem het binne verskeie sosiale strukture. Hy maak sosiale faktore los van die wesenlike van die modelle.

Uit die vorige afdeling oor die Bybelse modelle het dit duidelik geword dat hierdie modelle nie direk en universeel in vandag se tyd gebruik kan word nie. Daar is elemente in die modelle wat net nie meer in die een en twintigste eeu bruikbaar is nie. Tog is die riglyne wat die Bybel vir ons gee, nie onbelangrik nie. Inteendeel, die feit dat daar probleme binne die Bybelse tekste oor die huwelik is, maak dit soveel meer belangrik dat ons die tekste bestudeer, interpreteer en kontekstualiseer. Die Bybel bly tog die basis vir die Christelike beskouing van die huwelik. Maar hoe om hierdie basis te gebruik, gaan nie maklik wees nie. Wallace (2006:68) deel 'n belangrike les met ons oor Bybelse eksegese:

... biblical truth is not as obvious and straightforward as it may appear at first glance because the truth of the Bible can only be won by thoughtfully juxtaposing one interpretation over and against another through reference to a body of first principles or guiding rules that the interpreter considers to be self-evident and just ....

Ek sou voorstel dat 'n mens nie net een model verhef as die normatiewe by die Christelike huwelik nie. ' $n$ Mens moet liewer die verskillende Bybelse perspektiewe wat Thatcher noem, evalueer volgens Barton (1996:13) se "simfoniese hermeneutiek". Wallace (2006:67) sluit hierby aan deur te sê dat Bybellees eintlik ' $n$ intertekstuele saak is. Die relatiewe bydraes van verskillende interpretasies moet geweeg word in relasie met een of ander hoër prinsiep wat ' $n$ mens kan help om sin te maak van die individuele mengelmoes of selfs soms kakofonie van die Bybelgedeeltes. Die hoër, oorkoepelende prinsiep wat ek, soos Wallace (2006:73) wil gebruik, is liefde, die liefde van Jesus Christus wat die kanon agter die kanon is. Dus sal ons 'n kombinasie van perspektiewe uit die verskillende modelle gebruik wat 
betekenis kan gee aan huwelike vandag en liefde tussen mense en tussen mens en God ondersteun en opbou. Daarom is dit van belang om eers die essensiële sake van die Bybelse modelle wat vandag toepaslik is, te identifiseer.

\section{1 'n Verbond "vandag"}

Problematiese elemente binne die verbondsmodel oor die huwelik, is onder andere die volgende:die oordrag van goddelike mag aan die man en menslike feilbaarheid en sondigheid aan die vrou wat veroorsaak dat vroue as verbondsverbrekers gestereotipeer mag word; seksuele geweld en die verwysing dat alleenlik mans die inisiatief kan neem in die verhouding en die vrou passief moet bly (Thatcher 1999:87). Volgens Dreyer (2005:738) sou die aktiewe deelnemer noodwendig die een wees met hoër status, terwyl die passiwiteit van die ander persoon sy of haar laer status in die samelewing sou weerspieël. Garton (2004:33) stel dit soos volg: "Enforcing sexual submission or humiliation was a means of asserting dominance ..."

Vir Dreyer (2005:745-746) is dit uiters problematies om die "verbond" as normatiewe, preskriptiewe, Bybelse model vir die huwelik van vandag te gebruik omdat dit volgens haar neerkom op 'n modernistiese, essensialistiese siening van die Bybel. Die Bybel word dan naïef-realisties gebruik as 'n "van bo" objektiewe, goddelike openbaring. Volgens Van Huyssteen (1987:20) kom so 'n "fundamentalistiese" Skrifbeskouing daarop neer dat die Bybel gesien word as 'n geslote realiteit waarin die leser moet soek na die bedoeling wat die historiese skrywer vir alle tye daar geplaas het.

Ford (1984:16-56) lewer in haar artikel kritiek oor Karl Barth se beskouing van die verhouding man/vrou, omdat sy uitgangspunt van die "analogia relationis" kan neerkom op die subordinasie van die vrou aan die man. Dit moet toegegee word dat 'n mens versigtig moet wees om nie die verbondsverhouding te gebruik om die vrou tot 'n bepaalde onderdanige posisie te degradeer nie. Dit hoef egter nie noodwendig te beteken dat die verbond as metafoor vir die huwelik onbruikbaar is nie.

Elemente wat betekenisvol kan wees vir die verstaan van die huwelik as 'n verbond, is die volgende:die huwelik is 'n ooreenkoms tussen twee persone, waar albei instem tot dieselfde voorwaardes; die huwelik is nie 'n kontrak nie, maar 'n verbond, omdat God die getuie is van hierdie kontraksluiting; 'n Christelike huwelik is 'n verhouding (verbond) tussen man en vrou wat in die teenwoordigheid van God bekragtig word; 'n Christelike huwelik is 'n verbond tussen gelykes, tussen mans en vroue wat gelyke ontvangers is van die liefde van Christus; die menslike verbond van die 
huwelik is 'n deelname aan en afbeelding van die God-mensverbond tussen Christus en die Kerk (Thatcher 1999:87-95).

Van Aarde (2006) verstaan die verbondskarakter van die huwelik egter heel anders in terme van die Reformatoriese teologie en die idees van die Bybelse tyd. Hy glo dat die rede waarom die huwelik as verbond gesien word, die gevolg is van onder andere heteronormatiwiteit wat sowel sosio-kultureel, as sosio-religieus, geografies wyd en temporeel lank, die heersende ideologie was.

Ons is egter nie teologies genoodsaak om óf die huwelik óf ander intieme relasies as 'n "verbond" voor te stel nie. Wanneer dit gedoen word, behoort die begrip "verbond" deeglik deurskou te word, sodat die (semantiese en semiotiese) boustene daarvan raakgesien word.

(Van Aarde 2006)

Daarom beskou hy die verbondsdimensie problematies: "Om teologies en kerklik die heteroseksuele huwelik of enige ander vorm van sosiale intimiteit as 'instelling van God', of as 'enigste ruimte' of selfs as 'ideale ruimte' te sien, is om in die valstrik van burgerlike teologie te val." Daarom stem Van Aarde nie saam met van Wyk (2002:275) se siening dat die monogame huwelik op grond van die Bybelse norm die enigste model is waarbinne een man en een vrou saam 'n lewenslange verhouding kan hê nie. Van Wyk (2002:275) glo die huwelik is gebaseer op die verhouding van man en vrou met God, en dit is hierdie verhouding met God wat aan die huwelik 'n verbondskarakter verleen.

Van Aarde is myns insiens korrek as hy sê dat 'n mens die begrip, "verbond" baie duidelik sal moet definieer sodat misverstande vermy kan word ${ }^{17}$. Een van die misverstande kan wees dat "verbond" beteken dat die huwelik 'n instelling van God is. Hierdie afleiding hoef nie noodwendig vanuit die verbondsgedagte gemaak te word nie omdat die "verbond" iets wil beklemtoon van die aard van die verhouding en nie dui op 'n sakramentele karakter nie.

Ek dink dat Thatcher 'n begrip van verbond in gedagte het wat van hulp kan wees. Thatcher identifiseer hoe die gebruik van die verbondsmodel wat ons in die Bybel kry die hedendaagse huwelik kan verryk, sonder om die problematiek wat daarmee saamgaan in te trek. Dit help ons ook om die

\footnotetext{
${ }^{17}$ Soos reeds genoem in 3.1, is daar verskille binne die Reformatoriese teologie tussen die terme "foedus" en "testamentum". "Testamentum" as verbond is meer eensydig en hiërargies. In teologiese sin skep dit minder probleme omdat die God-mens verhouding noodwendig hiërargies is, maar sosiologies is dit baie problematies.
} 


\section{Bybelse modelle van die huwelik: 'n Kritiese perspektief}

verskille raak te sien tussen 'n Christelike huwelik en diè van 'n gesekulariseerde samelewing wat vroeër in tabelvorm genoem is.

Die verbondsmodel bring, volgens my, die uiters belangrike Goddelike dimensie weer in die huwelik na vore. Daarsonder verloor die huwelik as instelling geloofwaardigheid en word dit byna sinloos. Die ongelykheid binne ' $n$ verbondsverhouding, is volgens my, nie noodwendig tussen man en vrou nie, maar tussen die huweliksmaats en God. Die ongelykheid bestaan in die mens se ondergeskiktheid aan God, en nie aan mekaar nie. In hierdie verband is dit belangrik om daarop te let dat Efesiërs 5 juis dit wil beklemtoon dat die wedersydse ondergeskiktheid aan mekaar begrond is in beide partye se onderdanigheid aan God. Dit gaan dus nie in die eerste plek om meerderof minderwaardige persone nie, maar om albei se verhouding voor God. Gelykheid binne 'n huweliksverbond moet beklemtoon word, maar dit kan alleenlik gestalte kry indien dit voortvloei uit die geloofsrelasie met God.

\subsection{Vleeslike eenwording "vandag"}

Vleeslike eenwording gesien vanuit die patriargale sisteem, is gebruik om die vrou in te trek in die identiteit van die man. So word die vrou dan 'n toevoegsel tot die "vlees" van die man, permanent afhanklik van hom en ondergeskik aan hom. Hierdie idee kom oorspronklik vanuit die Genesisteks waar die man eerste geskep is en die vrou uit die man se liggaam geneem is. Dus bly die "een vlees" sy vlees, waarvan die vrou nou net deel word. Paulus het egter alreeds klem daarop gelê dat die liggame van die twee betrokke partye "gelyk verdeel" word omdat die vleeslike eenwording veroorsaak dat nie een van die twee se liggame meer net hulle eie is nie. Jesus het ook baie krities opgetree teenoor die feit dat mans om bykans enige rede van hulle vroue kon skei, terwyl vroue nie kon nie. Thatcher (1999:96) stel voor dat die "vleeslike" eenwordingsmodel soortgelyk hanteer word as die verbondsmodel: "it will be legitimately put forward as a non-sexist model of marriage and contrasted with secular accounts of marriage and of the person."

Die model van "vleeslike" eenwording is onmisbaar in die huwelik omdat dit die visie inhou van 'n lewenslange vennootskap wat deur Christus self erken word. Luther het egter, deur die huwelik te desakramentaliseer, die heilsnoodwendigheid daarvan weggeneem. Sommige mense interpreteer dit dat egskeiding daardeur geregverdig word. Luther het egter self gesê dat, alhoewel die huwelik nie 'n sakrament is nie, hy egskeiding so negatief bejeën dat hy bigamie bo dit sou verkies (Hendrix 2004:172, 176). Egskeiding moet veeleer gesien word as 'n praktiese probleem en hoef dus nie primêr prinsipieel regverdig te word nie. Dit rym ook met Luther se beskouing dat die huwelik 'n praktiese saak is. ' $n$ Lewenslange verbintenis is die ideaal, maar 
die praktyk kan soms egskeiding noodsaak. Omdat die huwelik nie 'n sakramentele karakter het nie, het egskeiding en hertrou dus nie vanselfsprekende negatiewe konsekwensies vir die mens se heil en saligheid nie.

As 'n mens die interpretasie van die Efesiër-teks gebruik om die Genesis-teks te verstaan kan ons ook tot die gevolgtrekking kom dat Genesis se "vleeslike" eenwording die volgende beteken: “... a lifelong ${ }^{18}$ union where each partner loves the other as that partner loves himself or herself ..." (Thatcher 1999:97). Volgens Hendrix (2004:174) het Luther op grond van Genesis 1:26-28 die afleiding gemaak dat die huwelik 'n deur God ge-"wil"de ordinansie is, alhoewel hy dit ook as 'n wêreldse instelling gesien het. Deur hierdie interpretasies te gebruik, word 'n reis begin wat omvat word deur die liefde van God deur Christus, en word dieselfde liefde wat Christus met sy kerk deel, met mekaar gedeel. Die relasionele van die huwelik word dus beklemtoon en nie individualisme nie. Huweliksmaats word "een" wanneer hulle soos Christus hulleself ten volle gee vir die ander persoon en ook die ander ontvang. Dit laat toe dat elkeen se identiteit gedeeltelik bepaal kan word deur sy of haar huweliksmaat. Daarom is persone binne so 'n verhouding van eenwording altyd persone-in-relasie. Alistair McFadyen (1990:40) stel dit só: "... persons are what they are for others or, rather, the way in which they are for others..."

Die model van "vleeslike eenwording" kan huwelike van vandag diepte en betekenis gee. Die veronderstelling dat 'n persoonlike eenheid, wat aan beide man en vrou 'n nuwe identiteit verleen, sodat die een party is wie hy of sy is, in relasie met die ander party, hou ook tegelykertyd 'n verantwoordelikheid in. Omdat twee partye deel het aan een identiteit, kan nie een van die twee partye totaal individualisties dink en optree nie, maar veronderstel dit dat die ander persoon in ag geneem sal moet word in enige besluitnemingsproses. Hierdie eenheid is 'n eenheid in Christus wat Homself volledig kon prysgee. Dit veronderstel dat mense in 'n Christelike huwelik ook bereid sal wees om hierdie groot opoffering te maak om mekaar lief te hê en aan mekaar onderdanig te wees soos aan Christus. Hierin lê die "geheim" van die huwelik opgesluit. Dit skep die geborge ruimte waarin seksuele eenwording, sonder uitbuiting en misbruik, tot verwesenliking kom.

Eenwording het verskillende fasette. Dit begin op die vlak van psigiese intimiteit tussen man en vrou waar daar voldoende wedersydse vertroue is om

\footnotetext{
${ }^{18}$ Dit is debatteerbaar of die Bybelse perspektiewe op die huwelik by implikasie ' $n$ lewenslange verbintenis beteken. Daar is geen eenduidige Bybelse verwysings na 'n lewenslange verbintenis nie. Die kerk het egter in sy teologiese refleksie oor die huwelik en na aanleiding van sosiale gebruike die sinvolheid vna die bedoeling van 'n lewenslange verbintenis teologies regverdig.
} 


\section{Bybelse modelle van die huwelik: 'n Kritiese perspektief}

in hulle kommunikasie hulle diepste emosies met mekaar te deel. Hierdie wedersydse openhartigheid, vertroue en ontboeseming lei daartoe dat mense geestelik na mekaar toe groei. In 'n sekere sin sou 'n mens eenwording kon definieer as die man en vrou se poging om, binne 'n verhouding van geborgenheid, vertroue en diensbaarheid, deur wedersydse begrip geestelik een te word. Intimiteit op psigologies-emosionele vlak, skep die behoefte tot volledige eenwording ook op liggaamlik-seksuele vlak. Seksuele eenwording is dus die manifestering van 'n dieperliggende emosionele verbintenis. Navorsing op die terrein van die psigologie en die sosiologie bevestig juis die noodsaaklikheid van hierdie eenwordingsproses as die basis vir seksuele geluk. Seksuele intimiteit word beskou as die diepste en mees intieme vorm van kommunikasie. Louw (1985:124) stel dit soos volg:"Seksualiteit is 'n erotiese soeke na afronding en volledigheid wat in 'n duursame psigofisiese eenheid kulmineer en op liefdevolle persoonskommunikasie gerig is. Dit het dus te doen met die etiese aspek van seks, naamlik seks as 'n verantwoordelikheid."

\section{3 'n Twyfelagtige noodsaaklikheid "vandag"}

Die pessimisme en androsentrisme van hierdie model kan veroorsaak dat die twyfelagtigheid van die huwelik oorbeklemtoon word en die noodsaaklikheid verdwyn. Soos mans in die verlede, kan vroue vandag sê dat hulle Christus beter kan dien as hulle nie getroud is nie. Die omgekeerde kan ook waar wees wanneer daar veronderstel word dat God net gedien kan word in 'n verbonds-verhouding met God wat alléén in die huwelik tot sy reg kom.

Ek dink nie een van die twee stellings kan verhef word as die simfoniese perspektief van die wysheidsliteratuur nie. Die ideaal is wel dat die Christelike huwelik 'n simbool is van die verenigende liefde van God, en tog beteken dit aan die ander kant nie dat die huwelik vir almal bedoel is nie. Daar is ander maniere om jouself in liefde te gee.

\section{4 'n Wêreldse vergunning "vandag"}

Die groot probleem met hierdie model is dat dit die siening laat ontstaan dat die huwelik slegs 'n "lisensie" is om seksueel aktief te raak. 'n Verbond wat opofferende liefde inhou, word nie in gedagte gehou nie.

Paulus noem dit 'n gawe om jouself te onthou van die huwelik en seksuele omgang, terwyl Thatcher (1999:100) dit weer 'n roeping noem om in die huwelik te tree. Met ander woorde, indien jy nie so 'n roeping ontvang nie, moet jy nie trou nie. Hendrix (2004:173) meen egter Luther het die teks uit 1 Korintiërs 7 nie verstaan as dat dit beter is om selibaat te bly nie. Luther interpreteer vers 7 (waar gesê word dat elke mens besondere gawes van God 
ontvang het) in die sin dat die huwelik ook een van die gawes is, 'n gawe wat baie meer mense ontvang as die gawe van 'n selibate lewe. Verder voer hy die argument dat die huwelik meer religieus is as 'n selibate lewe, omdat dit 'n mens dryf in die rigting van geloof en die Gees, en byna totaal uit geloof moet bestaan om te floreer.

Die problematiek van Jesus se woorde in die Evangelie van Lukas, waar daar gesê word dat die huwelik 'n mens se verlossing in gevaar kan stel, word verskillend hanteer. Volgens Brown (1989:41-42) moet 'n mens hierdie uitspraak kontekstueel beskou, in die tyd na die val van Jerusalem. Die rede vir hierdie uitspraak was, volgens hom: “... to meet the needs and to validate the activities of a group of wandering preachers..." Thatcher (1999:100) sê egter ook dat Christene wat toegewyd is aan die huwelik, strategieë kan gebruik om hierdie uitspraak uit die weg te ruim. Volgens hom kan hierdie model bruikbaar wees om mense bewus te maak van die destruktiewe elemente van die huwelik. Hy noem onder andere: "an oblivious disregard of the wider world beyond the family ... a spirit of selfishness and possessiveness which the maintenance of an affluent home encourages, and all those other features of marriage which led to the title 'unholy misery'..."

Botha (2006:128) glo dat ons eers bewus daarvan moet raak dat ons vandag nog dikwels 'n houding het wat inherent wantrouig is teenoor 'n mens se liggaamlikheid. In die antieke wêreld van die Nuwe Testament het byna almal hierdie sarkofobiese houding aanvaar. Hier kan ons iets van die OuTestamentiese holistiese siening van die mens, en 'n meer sarkofiliese siening van die liggaam gebruik. Die sarkofiliese houding van aanvaarding en erkenning van die liggaam gaan hand aan hand met die besef dat ek nie net 'n liggaam het nie, maar dat ek 'n liggaam is. Seks binne die huwelik en die huwelik self is dan nie maar net 'n vergunning vir mense wat nie hulle drange kan beheer nie, maar iets wat ek is, omdat ek slegs deur my liggaam voor God kan lewe. 'n Vrou se liggaam en haar liggaamlikheid kan dan nooit as minder of minderwaardig beskou word nie.

\subsection{Passievolle wedersydse liefde "vandag"}

Uit die ander modelle het dit duidelik geword dat ongelykheid en androsentrisme 'n skewe beeld van die Bybelse perspektief op die huwelik kan plaas. In Hooglied kry ons egter 'n ander perspektief. "Die Bybel in sy geheel, kies dus nie net vir een standpunt nie, maar skep interessant ruimte vir 'n tradisionele huwelik en óók 'n Hoogliedsituasie" (Viviers 2006:103).

Hooglied is een van die min boeke wat die tradisionele rolle tussen man en vrou omkeer. Binne 'n patriargale samelewing is dit 'n kontroversiële standpunt omdat gelykheid tussen man en vrou ondenkbaar was (vgl Lotter \& 


\section{Bybelse modelle van die huwelik: 'n Kritiese perspektief}

Steyn 2005:70-89). Daarom hef Hooglied se verwysing na naaktheid ook klasseverskille op. Volgens Whedbee (1993:266-278) is die naaktheid reeds 'n relativering van genderhiërargie waar man en vrou beide blootgestel voor mekaar staan. Hooglied se kontroversiële openheid teenoor erotiese liefde kan ook bydra tot die hedendaagse huwelik. "Dit is opvallend hoe spontaan en openlik die Hoogliedverliefdes mekaar se naaktheid geniet en so die etos van die Israelitiese 'respektabelheid' bevraagteken" (Viviers 2006:95).

Die hele Ou-Testamentiese holistiese siening van die mens kan bydra om hierdie skeiding te oorbrug. Die feit dat God as persoon afwesig is binne die Hoogliedboek hoef ook nie problematies te wees nie. Eilberg-Schwartz (1990:191) stel dat 'n vrou-vriendelike boek soos Hooglied moeilik eer kan betoon aan 'n patriargale God (Jawhe) in wie se godsdiens vrouwees per definisie beteken om "onrein" te wees. LaCoque (1998:31) meen dat in Hooglied transendentalisme plek gemaak het vir panenteïsme, waar God oral geruik, geproe, gevoel, gehoor en gesien kan word.

Dit is belangrik om die simfoniese klanke van Hooglied te identifiseer. Dit is vir my in die eerste plek die gelyke verhouding tussen man en vrou, en verder die waardering van erotiese liefde as ' $n$ gawe van God. Ten spyte van die tyd waarin ons leef, is daar nog vele mense, veral Christene wat geïnhibeer word deur dit wat hulle ouers en grootouers hulle geleer het (of nie geleer het nie) van seksuele omgang. Dit was 'n verbode onderwerp en mense is daarom dikwels uitermate skaam oor hulle liggame en seksualiteit asook dié van ander. Seksualiteit en spiritualiteit is so vér van mekaar verwyder. Erotiese liefde word dan ervaar sonder enige verband met die liefde van God vir alle dinge.

Thatcher (1999:121) sê dat Goddelike liefde manifesteer in menslike liefde, en daarom veroorsaak hierdie breuk tussen spiritualiteit en seksualiteit, dat die moontlikheid om 'n betekenisvolle ervaring te ontdek en in geloof te groei, gemis word. Hierdie standpunt van Thatcher dat goddelike liefde in menslike liefde manifesteer, kan egter daarop neerkom dat die liefde tussen man en vrou 'n ontiese karakter kry wat dit wesenlik gelykstel aan die liefde tussen God en mens. Dit is gevaarlik om hierdie gelykstelling te impliseer. Die standpunt van Karl Barth, om liewer te praat van 'n "analogia relationis" sal beter tot uitdrukking bring dat die liefde tussen man en vrou nooit wesenlik gelykgestel kan word aan die liefde van God vir mense nie, maar hoogstens na analogie van God se liefde tot uitdrukking kan kom. Die verdere probleem wat by implikasie in Thatcher se standpunt na vore kom, is die verbintenis in die premoderne paradigma tussen religie, huwelik en seks. Hiervolgens was seksuele verkeer in spirituele sin 'n uitdrukking van die verhouding tussen god/e en mense. Binne 'n postmoderne spiritualiteit word hierdie soort 
religieuse konneksie opgehef (vgl Dreyer 2006). Die uitdaging aan die teologie van vandag is om binne 'n postmoderne konteks die begrip "mensmens" liefde so te definieer en met inhoud te vul, na analogie van God se liefde vir mense, sonder om dit aan mekaar gelyk te stel.

\section{SLOTOPMERKING}

Die bespreking en evaluering van die Bybelse modelle wat Thatcher geïdentifiseer het, is in sekere opsigte baie waardevol. Tog kom 'n mens uit die voorafgaande afdeling agter dat al vyf modelle nie ewe bruikbaar is vir vandag nie. Die Bybel gee nie oor alles voorskrifte nie. Daarom is dit nodig om ook na die hedendaagse konteks te gaan kyk, sekere praktyke en problematiek wat verband hou met die huwelik te identifiseer en daaroor uitspraak te lewer. Die gegewens wat ons wel uit die Skrif kry, moet ons noukeurig ondersoek en binne konteks lees. Hierdie navorsing sal weergegee word in die tweede artikel.

\section{Literatuurverwysings}

Anderson, B W 1993. Covenant, in Metzger, B M \& Coogan, M D (eds), The Oxford Companion to the Bible. Oxford: Oxford University Press.

Barth, K 1961. Kirchliche Dogmatik, III. Zürich: EVZ-Verlag.

Barton, S C 1996. Is the Bible good news for human sexuality? Reflections on method in Biblical interpretation, in Thatcher, A \& Stuart, E (eds), Christian perspectives on sexuality and gender, 4-13. Grand Rapids, MI: Eerdmans.

Berkouwer, G C [1962] 1968. Man: The image of God, tr by D W Jellema. Grand Rapids, MI: Eerdmans. (Studies in Dogmatics.).

Black, J 2004. "Sanctity" and sanctimony in, Baird, R M \& Rosenbaum, S E (eds), Same sex marraige: The moral and legal debate, 97-98. Amherst, NY: Promettheus Books.

Bosman, D 1979. Ezra's marriage reform: Israel redefined. Biblical Theology Bulletin 9, 32-38.

Botha, P J J 2006. Die lyf: Fasette van die erotiese en seksuele in die Romeinse Ryk. Verbum et Ecclesia 27(1), 107-130.

Brown, P 1989. The body and society: Men, women and sexual renunciation in early Christianity. London: Faber \& Faber.

Donahue, J R \& Harrington, D J 2002. The Gospel of Mark. Collegeville, MN: The Liturgical Press. (Sacra Pagina 2.)

Dreyer, T F J 2006. Die akkommodering en bestuur van diversiteit in gemeenteverband. HTS 62(4), 1291-1309.

Dreyer, Y 2005. Sexuality and shifting paradigms - setting the scene. HTS 61(3), 729-751.

Eilberg-Schwartz, H 1990. The savage in Judaism: An anthropology of Israelite religion and ancient Judaism. Bloomington, IN: Indiana University Press. 
Ford, J C 1984. Toward an anthropology of mutuality: A critique of Karl Barth's doctrine of the male-female order as $A$ and $B$ with a comparison of the panentheistic theology of Jürgen Moltmann. PhD dissertation, Northwestern University. Ann Arbor, MI: University Microfilms International.

Groenewald, A 2006. Drink met vreugde uit die liefdesfontein! 'n Ou-Testamentiese perspektief op menslike seksualiteit. Verbum et Ecclesia 27(1), 42-69.

Hendrix, S 2004. Luther on marriage, in Wengegert, T J (ed), Harvesting Martin Luther's reflections on theology, ethics and the church, 169-184. Grand Rapids, Ml: Eerdmans.

Hugenberger, G P 1994. Marriage as a covenant: A study of Biblical law and ethics governing marriage developed from the perspective of Maleachi. Leiden: Brill. (VT Sup 52.)

King, C 2006. Song of Songs, in Guest, D et al (ed), The Queer Bible Commentary, 356-370. London: SCM.

Koosed, J L 2006. Ecclesiastes/Qohelet, in Guest, D (ed), The Queer Bible Commentary, 325-337. London: SCM.

LaCoque, A 1998. Romance she wrote: A hermeneutical essay on the Song of Songs. Harrisburg, PA: Trinity Press International.

Le Roux, J H 2006. Die lyf se troos. Verbum et Ecclesia 27(1), 26-41.

Liedboek van die Kerk 2001. Kaapstad: NG Kerk-Uitgewers.

Loader, J A 1979. Polar structures in the book of Qohelet. Berlin: De Gruyter.

Lotter, G A \& Steyn, R S 2005. Hooglied: Hedendaagse paradigma vir romantiese verhoudings. Verbum en Ecclesia 26(3), 70-89.

Louw, D J 1984. Versoening in die huwelik. Pretoria: Butterworth.

May, H G 1932. The fertility cult in Hosea. Languages and Literatures 48, 73-89. (American Journal of Semitics.)

McFadyen, A I 1990. The call to personhood: A Christian theory of the individual in relationships. Cambridge: Cambridge University Press.

Middleton, J R \& Walsh B J 1995. Truth is stranger than it used to be: Biblical faith in a postmodern age. Downers Grove, IL: InterVarsity.

Milner, B C 1970. Calvin's doctrine of the church. Leiden: Brill.

Murphy, R E 1990. A commentary on the book of Canticles or Song of Songs. Minneapolis, MN: Fortress.

Osiek, C 2006. The New Testament teaching on family matters. HTS 62(3), 819-843.

Palmer, P F 1972. Christian marriage: Contract or covenant? Theological Studies 33, 617-665.

Rogers, J 2006. Jesus the Bible and homosexuality. Louisville, KY: John Knox.

Schlier, H 1957. Der Brief an die Epheser. Düsseldorf: Patmos-Verlag.

Stegemann, E W \& Stegemann, W 1999. The Jesus movement: A social history of its first century. Edenburgh: T \& T Clark.

Stuart, E 1994. Just good friends: Towards a lesbian and gay theology of relationships. London: Mowbray.

Stuart, E 2006. Proverbs, in Guest, D et al (ed), The Queer Bible Commentary, 325337. London: SCM.

Tatman, $L$ 1998. The yearning to be whole-enough or to feel something, not nothing: A feminist theological consideration of self-mutilation as an act of atonement. Feminist Theology 17, 24-38. 
Thatcher, A 1999. Marriage after modernity: Christian marriage in postmodern times. England: Sheffield Academic Press. (Studies in Theology and Sexuality 3.)

Trible, P 1984. Texts of terror: Literary feminist readings of biblical narratives. Philadelphia, PA: Fortress.

Van Aarde, A G. Vanaf die romantiek tot postmoderniteit. TEO 871 Ongepubliseerde Besprekingsdokument, Fakulteit Teologie, Universiteit van Pretoria.

Van Aarde, A G 2002. Gevorderde studie van inleidingsvraagstukke van die Pauliniese korpus. Module 453. Ongepublliseerde Studiemateriaal in NuweTestamentiese Wetenskap, Fakulteit Teologie, Universiteit van Pretoria.

Van Aarde, A G 2005. Interdissiplinêre module: Teologiese Hermeneutiek. Ongepubliseerde Studiemateriaal OTW 451. Fakulteit Teologie, Universiteit van Pretoria.

Van Eck 2007a. Die huwelik in die eerste-eeuse Mediterreense wêreld (I): Die vrou in 'n man se wêreld. HTS, 63(1), 81-101.

Van Eck 2007b. Die huwelik in die eerste-eeuse Mediterreense wêreld (II): huwelik, egbreuk, egskeding en hertrou. HTS 63(1), 103-128.

Van Eck E 2007c. Die huwelik in die eerste-eeuse Mediterreense wêreld (III): Jesus en die huwelik. HTS 63(2) 481-513.

Van Wyk, D J C jr 2002. Die Huwelik en seksualteit in 'n postmoderne samelewing. HTS 58(1), 264-282.

Viviers, H 2006. Huwelik of nie - wat van Hooglied? Verbum et Ecclesia 27(1), 90106.

Wallace, M I 2006. The rule of love and the testimony of the Spirit, in Padgett, A G \& Keifert, P R (eds), But is it all true?: The Bible and the question of truth, 6685. Grand Rapids, MI: Eerdmans.

Weems, R J 1989. Gomer: Victim of violence or victim of metaphor? Semeia 49, 87104.

Whedbee, J W 1993. Paradox and parody in the Song of Solomon: Towards a comic reading of the most sublime song, in Brenner, A (ed), 266-278.

Wolff, H W 1974. Hosea: A commentary on the book of the prophet Hosea. Philadelphia, PA: Fortress. 